\title{
PENTINGNYA MEMBERDAYAKAN PEGAWAI DALAM KONTEKS PERUBAHAN
}

\author{
Oleh : \\ Sunarta \\ FISE UNY
}

\section{Abstrak}

Derasnya arus perubahan yang massif dengan tingkat turbulensi yang tinggi seperti saat ini, memberdayakan pegawai (employee empowerment) adalah sebuah keharusan. Organisasi yang tidak mengembangkan dan memberdayakan pegawai yang dimiliki serta menutup diri dari percaturan global vang selalu berubah, maka hanya akan jadi penonton dan bukan jadi pemain.

Memberdayaan berarti memampukan (to able), memberi kesempatan (to allow), dan mengijinkan (to permit). Memberdayaan pegawai berarti memampukan dan memberi kesempatan untuk melakukan fungsi-fungsi manajemen dalam skala yang menjadi tanggungjawabnya, baik secara individı! maupun kelompok. Selain itu pemberdayaan juga dapat dipandang sebagai seni-dalam proses mendorong pegawai untuk bekerja secara optimal demi kepuasan pelangyan

Dalam implementasi pemberdayaan pegawai diperlukan tingkat kejujuran yang tirggi, keterbukaan, dan integritas pada manajemen puncak, sehingga pemberdayaan bukan sekedar pemberian delegasi dari pimpinan kepada pegawai dibawahnya, tetapi lebih pada apa dan bagaimana sistem nilai dalam organisasi tersebut dipatuhi. Proses pemberdayaan pegawai suatu organisasi, dapat dilakukan melalui lima tahap: (1) proses diseminasi iriformasi (informing), tahap (2) proses konsultasi (consulting), tahap (3) proses pengumpulan ide (sharing), tahap (4) proses pendelegasian (delegating), dan tahap (5) proses pemberdayaan (empowering).

Ada empat komponen atribut pokok organisasi perusahaan yang harus segera diperbaiki jika ingin tetap eksis dalam kancah persaingan global, yakni (1) berorientasi pada pelanggan dan kualitas (customer and quality driven), (2) efektivitas pendapatan dan biaya (revenue and cost effective), (3) kecepatan 
dan fleksibilitas dalam merespon perubahan pasar (fast and flexible in responding to market changes), dan melakukan inovasi secara berkelanjutan (continually innovating).

Keberhasilan organisasi yang hidup di masa kini dan masa mendatang akan ditentukan oleh faktor kecepatan, fleksibilitas, integritas, dan inovasi dalam memenangkan setiap pesaingan. Sebuah paradigma baru organisasi moderen menganggap bahwa setiap orang adalah pemimpin (leadership from everybody), sehingga melalui pembentukan mindset tersebut pegawai berkesempatar memacu mengembangkan bakat kepemimpinannya. Dengan berkembangnya potensi sebagai pemimpin dan mampu mengembangkan kualitas, kompetensi, serta komitmen yang ada pada setiap pegawai, maka akan mempermudah di dalam melakukan alignment visi pribadinya dengan visi organisasi dimana pegawai tersebut bernaung.

(Kata kunci: pemberdayaan, pegawai, dan kepuasan konsumenj

\section{Pendahuluan}

Di tengah derasnya arus perubahan yang massif dan perfasif pada abad 21 saat ini, organisasi baik swasta maupun pemerintah selalu dituntut untuk bisa menyesuaikan dengan perkembangan zaman. Sebagaimana telah dipahami bersama bahwa saat ini, kita telah berada di tengah-tengah zaman atau era kesejagadan (global) yang penuh dengan persaingan (competition) dan tuntutan untuk terus bergerak maju menjauh dari para pesaing (competitor) yang ada.

Oleh Kendal, 1997 dalam Bambang Saptono, 2006 dinyatakan bahwa abad 21 dinamakan sebagai era of human capital, yaitu bergesernya orientasi masyarakat dari agraris dan industri (kapitalis) menuju masyarakat ilmu (knowledge so-ciety). Masyarakat ilmu nantinya akan memiliki posisi tawar (bargain-ning position) yang baik sejalan de-ngan bergesernya paradigma lama (kapitalis) menuju masyarakat tei-didik (educated society). Timbulnya gejala globalisasi berpangkal dari sifatsifat manusia yang tidak mau berhenti berpikir dan menciptakan hal-hal baru di berbagai bidang, terutama di bidang teknologi yang dibarengi pula oleh peningkatan kualitas SDM yang berlembang dengan pesat, Jusuf Suit-Almasdi, (1996 :130).

Sebuah lingkungan masyarakat (baca organisasi), baik dalam 
lingkup kecil maupun besar jika anggotanya telah diorientasikan untuk menjadi orang-crang terdidik, maka akan melahirkan Sumber Daya Manusia (SDM) yang memiliki kualitas dan kornpetensi yang memadai. Dengan tersedianya kualitas SDM yang demikian, maka setiap perubahan dan persaingan akan bisa diantisipasi sekaligus dimenangkan. Sumber Daya Manusia (baca: pimpinan, manajer, bawahan, pegawai, karyawan) yang dulunya hanya dianggap sebagai faktor produksi, akan dipandang lebih sebagai asset yang miemiliki daya tawar tinggi dalam mewujudkan tujuan yang telah direncanakan.

Pada konteks perubahan yang massif dengan tingkat turbulensi yang tinggi seperti saat ini, memberdayakan pegawai (employee empowerment) adalah sebuah keharusan. Organisasi yarig tidak mengembangkari dan memberdayakan pegawai yang dimiliki serta menutup diri dari percaturan globai yang selalu berubah, maka hanya akan jadi penonton dan bukan pemain.

Begitu ketatnya persaingan yang terjadi sekarang ini, maka perusahaan harus selalu mengikuti apa yang sedang dan akan terjadi. Oleh Ken Blancard, (2002:3), bahkan diingatkan bahwa perusahaan saat ini harus mengubah orientasi bisnisnya jika tidak ingin hancur ditelah persaingan dalam era perubahan. Ada empat komponen atribut pokok organisasi perusahaan yang harus segera diperbaiki jika ingin eksis, yakni (1) berorientasi pada pelanggan dan kualitas (custorner and quality driven), (2) efektivitas pendapatan dan bi-aya (revenue and cost effective), (3) kecepatan dan fleksibilitas da-lam merespon perubahan pasar (fast and flexible in responding to market changes), dan melakukan inovasi secara berkelanjutan innovating).

\section{Pemberdayaan}

(con-tinually

pegawai sebenarnya telah menjadi trend sebagi bagian dari sistem pengelolaan sumber daya manusia yang berorientasi masa depan (future oriented) demi kepuasan konsumen (customer satisfaction). Konsumen yang hasus akan bentuk-bentuk pelayanan berkualitas, prima, dan memuaskan memberi tantangan baru bagi organisasi dalam mengeiola berbagai sumber daya yang dimiliki. Melalui usaha pemberdayaan pegawai sebagai bagian dari salah satu unsur sumber daya organisasi, maka dalam jangka panjang organisasi akan mampu secara optimal memanfaatkan sumber daya manusianya di tengah persaingan global.

\section{Pemberdayaan dan Visi Organisasi}

Runtuhnya tatanan sistem organisasi pada umumnya ditandai dengan (1) lemahnya visi yang dimiliki pemimpin, (2) tidak adanya dukungan dari para bawahan/ pe- 
ngikut, (3) tidak tersedianya dukungan dana, (4) munculnya konflik organisasi secara vertikal maupun horizontal, dan (5) akibat perubahan budaya organisasi yang ti-dak diimbarıgi dengan penciptaan sis-tem, struktur, dan share mindset se-suai tuntutan organisasi. Lemahnya kualitas SDM sebagai pemimpin organisasi akan rentan terhadap berbagai persoalan yang muncul dalam praktek kepemimpinannya.

Tidak adanya dukungan dari para bawahan/pegawai dalam suatu kepemimpinan, disebabkan oleh rendahnya tingkat kesejahteraan dan minimnya pertatian (apresiasi) yang diberikan oleh pimpinan. Disamping itu, langkanya kesempatan dan peluang para pegawai untuk memberdayakan dirinya dalam mengksploitasi seluruh kemampuan dan keterampilan yang dimiliki menjadi penyebab mengapa seorang pimpinan tidak memperoleh dukungan secara baik.

Pegawai yang berdaya akan banyak memberi keuntungan, baik dirinya sendiri, kelompok, dan terlebih lagi bagi organisasi. Dalam jangka panjang, pegawai yang diberdayakan akan memberikan gagasan dan inisiatif bagi organisasi dalam menyelesaikan setiap permasalahan yang dihadapi. Kepedulian dan rasa memiliki (sense of belong) yang tinggi terhadap berbagai isu dan permasalahan organisai, disadari atau tidak hal itu merupakan bentuk nyata sumbangan pemikiran pegawai yang sangat mahal dan tak ternilai. Namun semangat pegawai dalam menuang-kan ide dan gagasan dalam bekerja harus dipandu dengan bekal visi dan misi organisasi yang kuat. Hal ini penting karena visi sebagai sesuatu harapan, keinginan, citia-cita, harus dipahami dan dimengerti oleh seluruh anggota organisasi agar dalam mewujudkan visi terse-but tidak mengalami salah arah yang mengakibatkan kegagalan.

Secara sederhana, visi dapat diterjemahkan sebagai masa depan yang realisits, dapat dipercaya, dan menarik bagi organisasi, Burt Nanus, (1981:9). Masih menurut Nanus, visi merupakan pernyataan tujuan, sebuah masa depan yang lebih baik, lebih berhasil, atau lebih diinginkan dibandingkan dengan kondisi sekarang. Visi seorang pemimpin pada dasarnya akan dapat menumbuhkan motivasi dan menginspirasi setiap tindakan bawahan dalam melaksanakan tugas yang diberikan pemimpinnya. Secara lebih luas visi seorang pemimpin dapat membantu membentuk masa depan organisasi yang dipimpinnya.

Pemimpin yang tidak
mampu merumuskan visi, misi,
tujuan, dan strategi yang jelas akan
mengalami kendala dalam pendis-
tribusian (break down) visi dan misi
tersebut kepada semua orang yang 
menjadi bawahannya. Jika hai ini terjadi, maka dapat dipastikan orangorang yang menjadi ba-wahan dalam praktek organisasi akan mengalami hambatan serius. Hambatan bawahan dalam menerima perintah dan melaksanakan tugas biasanya disebabkan karena minim-riya informasi dan ketidakjelasan tu-juan yang diberikan oleh pemim-pinnya. Pada kondisi seorang pemimpin tidak mampu mem-break down visi, misi, dan tujuan organisasi secara komprehensif dan simultan, memiliki kecenderungan memuncul-kan konflik internal yang diikuti oleh suasana kerja yang kacau dan massif.

Seorang pemimpin dikatakan berhasil, nıanakala mampu menerapkan pola kepemimpinannya secara efektif dan efisien sehingga bisa menjadi sumber dan kekuatan organisasi. Organisasi yang berhasil menurut Stoltz, (1997:198), harus mampu mengubah kendala dalam lingkungannya menjadi peluang untuk memajukan diri. Pemimpin yang memiliki visi masa depan yang kuat (visioner) dalam menjalankan roda organisasi untuk mencapai tujuan yang telah direncanakan sebelumnya, akan lebih mudah dibandingkan dengan pemimpin lainnya.

Organisasi yang memiliki pemimpin visioner akan sangat menentukan ketepatan dan kecepatan mencapi tujuan, sementara organisasi dengan tingkat kualitas sumber daya manusia yang baik akan memper- mudah mewujudkan harapan. Namun untuk mendapatkan sumber daya manusia yang memiliki kualitas dan kapasitias ideal seperti di atas tidak-lah mudah. Agar setiap tujuan organisasi mempunyai dampak yang positif terhadap kinerja pegawai, makatujuan itu pertamatama harus diterima oleh para pegawai. Penerimaan tujuan (goal acceptance) merupakan prasyarat (prerequisite) yang penting bagi adanya dampak positif terhadap tujuan organisasi, Herny Simamora, (1997:53).

Pada kasus tertentu, organisasi besar yang memiliki pemimpin visioner, namun tidak ditunjang dengan ketersediaan sumber daya manusia pendukung yang mampu menterjemahkan visi, misi, dan tlijuar, pemimpinnya niscaya hanya akэn melahirkan manusia robot yang tidak mau bekerja, berkreasi, dan berinovasi jika tidak diperintah. Begitu pula sebaliknya, memiliki sumber daya manusia dengan tingkat kualitas yang mencukupi tetapi tidak diikuti kemampuan dan kapasitas seorang pemimpin yang memiliki visi kuat, juga akan melahirkan kebingungan, ketidakjelasan, ketidakpastian, dan kekacauan.

Minimnya sumber daya manusia baik secara kuantitas maupun kualitas dalam suatu organisasi, dapat menghambat kece- 
patan pencapaian tujuan. Tidak tercukupinya jumlah dan standar kualitas sumber daya manusia yang unggul disatu sisi serta kurangnya upaya yang kuat (commitment) dari pimpinan untuk memberdaya-kannya disisi yang lain, dapat menye-babkan terganggunya praktek mana-jemen organisasi. Manajemen organi-sasi yang tidak dibangun dengan landasan komitmen yang kuat dari para pemimpin dan orang-orang yang terlibat di dalamnya, maka daur hidup organisasi (organisation life cycle) tersebut akan menjadi lebih pendek.

\section{A. Pemberdayaan suatu Kebutuhan Menurut Mulyadi, (2000:103),} pemberdayaan berarti memampukan (to able), memberi kesempatan (to allow), dan mengijinkan (to permit) yang dapat diartikan baik melalui inisiatif sendiri maupun dipicu orang lain. Pemberdayaan pegawai berarti memampukan dan memberi kesempatan kepada pegawai untuk melakukan fungsi-fungsi manajemen dalam skala yang menjadi tanggungjawabnya, baik secara individu maupun kelompok.

Sebagai individu kesempatan dalam melaksanakan fungsi-fungsi manajemen seperti (1) membuat perencanaan, (2) mengimplementasikan, (3) mengendalikan, dan (4) mengevaluasi tugas dan tanggungjawabnya merupakan bentuk aktualisasi kemampuan dan kompetensi seorang pegawai dihadapan pim- pinan. Sedangkan disisi pimpinan, aktualisasi yang ditunjukkan para pegawainya merupakan bagian dari persiapan terhadap pegawai handal yang diharapkan mampu menerima estafet kepemimpinan organisasi.

Organisasi yang berdaya akan dipenuhi oleh orang-orang yang memiliki kepedulian dan keterlibatan yang dapat membantu usaha pencapaian fleksibilitas, responsivitas terhadap pelanggan, dalam lingkungan bisnis yang menantang dan kompetitif. Seperti dikatakan oleh Ken Blancard, 2002, dikatakan bahwa pemberdayaan sebagai suatu cara untuk memwirausahakan (entrepreneurship) orang lain, penanaman rasa memiliki (ownership), suatu bentuk ikatan kerja atas dasar komitmen (enga$g \in$ ment), dan sebagai suatu usaha untuk membuat orang lain terlibat (involvement).

Pemberdayaan diartikan sebagai membagi kekuasaan (power sharing) atau mendelegasikan kekuasaan dan wewenang kepada bawahan di dalam organisas! (Daft, 1999). Dalam definisi lain oleh (Luthan, 1995), dalam Triantoro Safaria, (2004:210), dikatakan bahwa pemberdayaan adalah wewenang untuk membuat keputusan dalam kegiatan opersional individual tanpa harus memperoleh persetujuan dari siapapun.

Sedangkan menurut Safarudin Alwi, (2001:59), pemberdayaan 
merupakan seni-dalam proses mendorong pegawai untuk bekerja secara optimal. Pemberdayaan ti-dak cukup hanya dengan memba-ngun kemampuan dan memberinya peluang untuk berbuat, tetapi pemberdayaan juga berkaitan dengan nilai. Pemberdayaan memerlukan tingkat kejujuran yang tinggi, keterbukaan, dan irtegritas pada manajemen puncak. Dengan demikian pemberdayaan bukan sekedar pemberian delegasi dari pimpinan kepada pegawai dibawahnya, tetapi lebih pada sistem nilai dalam organisasi yang dianut.

Sistem nilai yang dianut organisasi seperti kejujuran, keterbukaan, dan kebersamaan menjadi jembatan antara pemimpin dengan pemimpin, bawahan dengan bawahan, dan pemimpin dengan bawaharı dalam proses pelaksanaan pemberdayaan bagi organisasi. Pola hubungan pemimpin dengan bawahan dan sebaliknya, jika tidak dilandasi atas nilai-nilai organisasi yang disepakati, maka dalam memberikan kesempatan, pemberian ijin, dan memampukan pegawai akan mengesankan sikap subjektiv dan perasaan ketidakadilan antar anggota organisasi.

Pegawai yang memiliki kapabilitas, kemauan, dan kesempatan sudah semestinya diberikan ruang untuk menjalankan tanggungjawabnya secara otonom. Selain itu, pegawai juga harus dilibatkan dalam membuat perencanaan, pengorgani- sasian, pengelolaan pekerjaannya agar lebih efektif dan efisien, Gery Dessler, (1997:285).

Pada dasarnya, pegawai dalam suatu organisasi akan merasa berdaya jika kepadanya mampu memperoieh informasi secara lengkap dan be-nar, (2) menerima otoritas dan me-mahami tanggungjawab secara jelas, dan (3) memahami persoalan yang diberikan pimpinan sekaligus mampu mencari solusinya. Bentukbentuk aktualisasi pegawai yang dapat mengoptimalkan peran dan fungsinya sebagai usaha pemberdayaan, akan membantu organisasi mencapai tujuan.

Dalam proses pemberdayaan pegawai suatu organisasi, menurut Johnson dan Redmond, (1998:10), sedikitnya melalui tahap (1) proses diseminasi informasi (informing), tahap (2) proses konsuitasi (consulting), tahap proses pengumpulan ide (sharing), tahap (4) proses pendelegasian (delegating), dan tahap (5) proses pemberdayaan (empowering). Secara lebih rinci kelima proses pemberdayaan di atas dapat dilihat dalam tabel sebagai berikut: 
sultasi (consulting), tahap (3) proses pengumpulan ide (sharing), tahap (4) proses pendelegasian (delegating), dan tahap (5) proses pemberuayaan (empowering). Se-cara lebih rinci kelima proses pem-berdayaan di atas dapat dilihat dalam tabel sebagai berikut:

\begin{tabular}{|l|l|}
\hline \multicolumn{1}{|c|}{ Tahap } & \multicolumn{1}{|c|}{ Sasaran (objek) } \\
\hline $\begin{array}{l}\text { Diseminasi } \\
\text { Informasi } \\
\text { (informing) }\end{array}$ & $\begin{array}{l}\text { Segala sesuatu yang berkaitan tugas dan tanggungjawab } \\
\text { pegawai dan hal-hal yang menentukan seperti informasi } \\
\text { tentang: problem yang dihadapi dan perubahan yang } \\
\text { mungkin terjadi, taktik dan strategi perusanaan, target yang } \\
\text { harus dicapai, dan kondisi perusahaan saat ini; }\end{array}$ \\
\hline $\begin{array}{l}\text { Konsultasi } \\
\text { (consulting) }\end{array}$ & $\begin{array}{l}\text { Berbagai masalah yang dihadapi oieh pegawai dalam kaitan } \\
\text { tugas dan tanggungjawabnya yang belum dimengerti } \\
\text { dengan jelas seperti: ketentuan upah, ketentuan gaji, dan } \\
\text { hasil penilaian kinerja; }\end{array}$ \\
\hline $\begin{array}{l}\text { Pengumpulan Ide } \\
\text { (sharing) }\end{array}$ & $\begin{array}{l}\text { Share pendapat atau ide tentang hubungan antar job dan } \\
\text { bagaimana mengatasi problem yang terjadi dalam } \\
\text { hubungan tersebut, ide tentang inovasi, perubahan, dan } \\
\text { share dalam pengambilan keputusan; }\end{array}$ \\
\hline $\begin{array}{l}\text { Pendelegasian } \\
\text { (delegating) }\end{array}$ & $\begin{array}{l}\text { Mendefinisikan dengar jelas tentang tugas dan } \\
\text { tanggungjawab, otoritas pengambilan keputusan, peiuang } \\
\text { bagi aktualisasi diri dalam konteks wewenang dan } \\
\text { tanggungjawab; ditas }\end{array}$ \\
\hline $\begin{array}{l}\text { Pemberdayaan } \\
\text { (empowering) }\end{array}$ & $\begin{array}{l}\text { Kualitas diri sebagai intelectual capital yang memiliki } \\
\text { keunggulan (human resource champion) dengan kompetensi } \\
\text { dan komitmen yang tinggi terhadap tugas dan } \\
\text { tanggungjawabnya. }\end{array}$ \\
\hline
\end{tabular}

Pendapat Johnson dan Remond di atas dipertegas oleh Ken Blancard Pemberdayaan sebagai berikut dengan apa yang disebutnya sebagai aplikasi Skema Proses

Vol. LX No. 1 Februari 200933 : 45 


\section{SKEMA PROSES PEMEERDAYAAN}

Berbagai informasi dengan setiap orang

- Berbagi informasi mengenai kinerja perusahaan membantu orang memahami bisnis

- Membangun kepercayaan melalui sharing

- Menetapkan kemungkinan-kemungkinan untuk pengawasan diri sendiri

- Memandang kesalahan sebagai kesempatan untuk belajar

- Menghilangkan pemikiran hirarkis, mendorong orang untuk bersikap memiliki

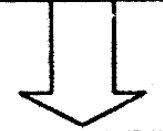

Menciptakan otonomi melalui batasbatas wewenang

- Memperjelas gambar besar dan gambar kecil

- Memperjelas tujuan dan peran

- Mendefinisikan nilai-nilai dan aturan yang melandasi tindakân

- Menciptakan aturan dan prosedur yang mendukung perriberdayaan

- Memberikan pelatihan yang diperlukan

- Meminta orang agar bertanggungjawab terhadap hasil tindakan

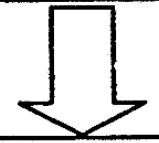

Mengganti pemikiran hirarkis dengan tim mandiri

- Memberikan pengarahan dan pelatihan keterampilan bagi tim-tim yang akan diberdayakan

- Memberikan dorongan dan semangat untuk berubah

- Memanfaatkan diversitas sebagai asset tim

- Secara bertahap meyerahkan pengawasan kepada tim

- Menyadari bahwa akan muncul masamasa yang sulit

Pentingnya Mernberdayakan Pegawai dalam Konteks Perubahan (Sunartc 
Oleh karena pemberdayaan dalam suatu organisasi menyangkut dua pihak yang berkepentingan, yakni pimpinan dan bawahan atau manajer dan karyawan, maka keduanya harus saling mendukung dan mendorong implementasi pemberdayaan tersebut. Dari sisi pimpinan, pegawai-pegawai yang ditargetkan akan diberdayakan adalah menjadi tanggungjwabnya. Pimpinan memiliki kewajiban bagaimana seseorang merasa berdaya, diberi peluang, difasilitasi, dan diberi kepercayaan dalam pengambilan keputusan yang sebelumnya dilakukan oleh pimpinan. Sedangkan dari sisi pegawai, pemberian kesempatan, fasilitas, kepercayaan, dan tanggungjawab harus dilaksanakan sebaikbaiknya sebagaimana ia sebagai remimpin.

Organisasi masa lalu, menempatkan seorang pimpinan sebagai responsibility of the top, sehingga pegawai hanya diposisikan sebagai alat produksi belaka. Sementara organisasi moderen saat ini dari yang akan datang, setiap orang yang menjadi anggota organisasi adalah pemimpin (leadership from everybody). Melalui pembentukan mindset bahwa setiap orang adalah pemimpin, maka pegawai akan terpacu mengembangkan bakat-bakat kepemimpinan yang dimilikinya. Dengan berkembangnya potensi sebagai pemimpin dan mampu mengembangkan kualitas, kompetensi, serta komitmen yang ada pada setiap pegawai, maka akan mempermudah di dalam melakukan alignment visi pribadinya dengan visi organisasi.

Di tengah pesatnya arus teknologi informasi sekarang ini, menurut Mulyadi, (2000:22), keberhasilan suatu crganisasi ditentukan oleh empat faktor masing-masing (1) kecepatan merespon perubahan kebutuhan customer, kecepatan mengubah strategi, kecepatan dalam membawa barang dan jasa ke pasar, dan kecepatan dalam menyediakan layanan bagi customer, (2) fleksibilitas personil dalam menyesuaikan diri dengan tuniutan perubahan lingkungan bisnis, kemampuan belajar keterampilan ba$r u$, dan kesediaan untuk bergeser ke lokasi dan penugasan baru yang belum peinah dikenal, yang menentukan keberhasilan organisasi di masa datang, (3) integritas atau keterpaduan seluruh anggota organisasi dan keterpaduan organisasi perusahaan dengan organisasi para pemasok, serta keterpaduan organisasi dengan customer, (4) kemampuan untuk menghasilkan inovasi produk dan proses baru untuk memenuhi kebutuhan customer. Secara dikotomis dan empiris paradigma keberhasilan organisasi masa lalu dan yang akan datang seperti diuraikan di atas dapat dilihat dalam tabel sebagai berikut: 


\begin{tabular}{|l|l|}
\hline $\begin{array}{l}\text { Faktor Keberhasilan Organisasi } \\
\text { Masa Lalu }\end{array}$ & \multicolumn{1}{c|}{$\begin{array}{c}\text { Faktor Keberhasilan } \\
\text { Organisasi Masa Kini }\end{array}$} \\
\hline$\bullet$ Ukuran & $\bullet$ Kecepatan \\
\hline - Kejelasan peran & $\bullet$ Fleksibilitas \\
\hline - Spesialisasi & $\bullet$ Integrasi \\
\hline - Pengendalian & $\bullet$ Inovasi \\
\hline
\end{tabular}

Dari tampilan yang ada dalam tabel di atas, memperlihatkan faktorfaktor keberhasilan organisasi masa lalu seperti ukuran, kejelasan peran, spesialisasi, dan pengendalian perlahan-lahan sudah mulai ditinggalkan. Sementara organisasi yang hidup di masa kini dan masa mendatang sejak awal telah mulai menggunakan faktor-faktor seperti kecepatan, fleksibilitas, integritas, dan inovasi sebagai bagian strategi dalam memenangkan setiap pesaingan.

Oleh Bill Gate dalam bukunya yang berjudul "The speed of throught" dikatakan bahwa dalam kurun waktu tahun 1980-an orang-orang berbicara soal mutu, kemudian selam tahun 1990-an orang-orang berbicara soal reengineering, dan pada tahun 2000 an banyak orang akan berbicara tentang kecepatan. Pada kontek kecepatan, baik kecepatan merespon perubahan kebutuhan customer, kecepatan mengubah strategi, kecepatan dalam membawa barang dan jasa ke pasar konsumen, dan kecepatan dalam menyediakan layanan bagi customer harus ditunjang dengan daya dukung personil yang berdaya, memiliki kapabilitas, kualitas, dan komitmen yang tinggi untuk merespon perubahan yang cepat tersebut.

Satu hal yang tidak boleh dilupakan dalam program pemberdayaan pegawai adalah sejauhmana upaya tersebut dapat memberikan nilai tambah, baik secara materiil maupun imateriil. Secara imateriil (intrinsik), seorang pegawai membutuhkan rasa kebanggaan, kesempatan, peluang, dan ruang untuk mengekspresikan kemampuan yang dimiliki dalam menerima tanggungjawab yang diberikan pimpinan. Namun di sisi lain sebagai pegawai yang hidup di tengahtengah masyarakat luas tentunya secara ekonomis juga membutuhkan penghasilan yang dapat mencukupi diri dan keluarganya. Jika organisasi dapat mewujudkan kedua kebutuhan tersebut, maka program pemberdayaan pegawai dalam jangka panjang akan menuai keberhasilan. 
Kesimpulan

Pada kontek perubahan yang massif dengan tingkat turbulensi yang tinggi seperti saat ini, memberdayakan pegawai (employee empoworment) adalah sebuah keharusan. Organisasi yang tidak mengembangkan dan memberdayakan pegawai yang dimiliki serta menutup diri dari percaturan global yang se!alu berubah, maka hanya akan jadi penonton dan bukan jadi pemain.

Memberdayaan berarti memampukan (to able), memberi kesempatan (to allow), dan mengijinkan (to permit). Memberdayaan pegawai berarti memampukan dan memberi kesempatan kepada pegawai untuk melakukan fungsi-fungsi manajemen dalam skala yang menjadi tanggungjawabnya, baik secara individu maupun kelompok. Selain itu pemberdayaan juga dapat dipandang sebagai seni-dalam proses mendorong pegawai untuk bekerja' secara optimal demi kepuasan customer. Dalam implementasi pemberdayaan diperlukan ingkat kejujuran yang tinggi, keieibukaan, dan integritas pada manajemen puncak, sehingga pemberdayaan bukan sekedar pemberian delegasi dari pimpinan kepada pegawai dibawahnya, tetapi lebih pada sistem nilai dalam organisasi yang dianut.

Dalam proses pemberdayaan pegawai suatu organisasi, menurut Johnson dan Redmond, (1998:10), sedikitnya melalui tahap (1) proses diseminasi informasi (informing), tahap (2) proses konsultasi (consulting), tahap (3) proses pengumpulan ide (sharing), tahap (4) proses pendelegasian (delegating), dan tahap (5) proses pemberdayaan (empowerwing).

Keberhasilan organisasi yang hidup di masa kini dan masa mendatang akan ditentukan oleh faktor kecepatan, fleksibilitas, integritas, dan inovasi dalam memenangkan setiap pesaingan. Sebuah paradigma baru organisasi modern menyatakan bahwa setiap orang adalah pemimpin (leadership from everybody), sehingga melalui pembentukan mindset tersebut seorang pegawai akan terpacu mengembangkan bakat-bakat kepemimpinan yang dimilikinya. Dengan berkem-bangnya potensi sebagai pemimpin dan mampu mengembangkan kuali-tas, kompetensi, serta komitmen yang ada pada setiap pegawai, maka akan mempermudah di dalam melakukan alignment visi pribadinya dengan visi organisasi dimana pegawai tersebut bernaung.

\section{Daftar Pustaka}

Burt Nanus, 2001. Kepemimpinan Visioner, Penhalindo, Jakarta.

Gary Dessler, 1997. Human Resource Management, Prentice Hall, USA.

Hadari Nawawi, 1997. Manajemen Sumber Daya Manusia untuk 
Bisnis yang Kompetitif, Gadjah Mada University Press, Yogyakarta.

Henry Simamora, 1997. Manajemen Sumber Daya Manusia, STIE YKPN, Yogyakarta.

Jusuf Suit, Almascii, 1996. Ȧspek Sikap Mental dalam Manaje-men Sumber Daya Manusia, Ghalia Indonesia, Jakarta.

Ken Blancard, 2002. Empowerment (Take More Than a Minute), Amara Books, Yogyakarta.
Mulyadi, Johny Setyawan, 2000. Sisiem Perencanaan dan Pengencialian Manajemen, Aditya Media, Yogyakarta.

Paul Hersey, Ken Blancard, 1982. Management of Organizational Behavior, Prentice Hall, USA.

Safarudin Alwi, 2001. Manajemen Sumber Daya Manusia (Strategi Keunggulan Kompetitif), BPFE Yogyakarta. Triantoro Safaria, 2004. Kepemimpinan, Graha IImu, Yogyakarta.

Biodata Penulis

Sunaita, SE, MM - PNS FISE UNY, pemerhati masalah organisasi, praktisi bisnis, dan dosen tidak tetap di Prodi Pemasaran D-3 Wates FISE UNY. 